\title{
UPAYA MENINGKATKAN KREATIVITAS BIOLOGI SISWA MELALUI PENERAPAN MODEL PROBLEM BASED LEARNING (PBL) DI SMA NEGERI 1 SIPIROK
}

\author{
Hoirunnisa nasution ${ }^{1)}$, Melvariani Syari Batubara ${ }^{1)}$ dan Muhammad Darwis ${ }^{1)}$ \\ ${ }^{1)}$ Program Studi Pendidikan Biologi, FKIP, Universitas Muhammadiyah Tapanuli Selatan, \\ Indonesia \\ e-mail: melvariani.syari@um-tapsel.ac.id
}

\begin{abstract}
Abstrak
Penelitian ini bertujuan untuk meningkatkan kreativitas, aktivitas siswa dan pengelolaan pembelajaran biologi melalui penerapan model pembelajaran Problem Based Learning (PBL) di kelas XI IPA-4 SMA Negeri 1 Sipirok T.P 2018/2019. Jenis penelitian ini adalah penelitian tindakan kelas (PTK) dengan menggunakan dua siklus pembelajaran. Tiap siklus dimulai dari perencanaan, pelaksanaan, pengamatan dan refleksi. Teknik pengumpulan data yang digunakan adalah tes dan observasi dengan alat pengumpulan data berupa lembar tes dan lembar observasi. Berdasarkan hasil penelitian yang dilakukan, diperoleh hasil tes pada siklus I dengan nilai rata-rata 71,84 jumlah siswa yang tuntas sebanyak 9 orang (71,97\%) dan pada siklus II diperoleh nilai rata-rata 93,59 jumlah siswa yang tuntas 30 orang $(93,75 \%)$ sehingga dari siklus I ke siklus II terjadi peningkatan sebanyak 7 orang (21,88\%). Adapun hasil observasi terhadap aktivitas belajar siswa pada siklus I diperoleh nilai ratarata 2.32 (58,28\%), siklus II 3,05 (76,56\%) peningkatan 18,28\% dari kriteria cukup menjadi kriteria baik. Adapun pengelolaan pembelajaran biologi dari siklus I diperoleh persentase rata-rata $70 \%$ dan pada sikulus II menjadi 91\%. Dengan demikian,dari siklus I ke siklus II terjadi peningkatan sebesar 21\% dari kulaifikasi cukup menjadi kriteria baik. Penelitian ini disudahi pada siklus II karena indikator keberhasilan telah tercapai dan memenuhi kriteria ketuntasan sehingga kesimpulan dari penelitian ini adalah bahwa melalui model pembelajaran Problem Based Learning (PBL), ternyata dapat meningkatkan kreativitas, aktivitas dan pegelolaan pembelajaran biologi siswa.
\end{abstract}

Kata Kunci: Kreativitas Belajar, Aktivitas Belajar, Problem Based Learning (PBL)

\begin{abstract}
This research aims to improve creativity, student activity and management of biological learning through the application of learning model of Problem Based Learning (PBL) in class XI IPA-4 SMA Negeri 1 Sipirok T. P 2018/2019. This type of research is class action research (PTK) using two learning cycles. Each cycle starts with planning, implementation, observation, and reflection. The data collection techniques used are tests and observations with data collection tools in the form of test sheets and observation sheets. Based on the results of the study, obtained the test result on the cycle I with an average value of 71.84 students who completed 9 people $(71.97 \%)$ And in cycle II was obtained an average value of 93.59 students over 30 people (93.75\%) So from cycle I to cycle II occurred an increase of 7 people (21.88\%). The results of the observation on student learning activities in cycle I were obtained an average value of 2.32 (58.28\%), Cycle II 3.05 (76.56\%) An increase of $18.28 \%$ of the criteria is quite good criteria. The management of biological learning from cycle I gained an average percentage of $70 \%$ and Sikulus II to $91 \%$. Thus, from cycle I to cycle II There has been an increase of $21 \%$ of the circulation enough to be a good criterion. This study was
\end{abstract}

PeTeKa (Jurnal Penelitian Tindakan Kelas dan Pengembangan Pembelajaran) $\mid 30$ 
Hoirunnisa Nasution, dkk. Upaya Meningkatkan Kreativitas Belajar Biologi Siswa...

terminated in cycle II because success indicators have been achieved and meet the criteria of submission so that through the model learning Problem-Based Learning (PBL), it can be increased Creativity, activity and management of biological learning of students

Keywords: Learning creativity, learning activity, Problem Based Learning

\section{PENDAHULUAN}

Pembelajaran merupakan suatu hubungan timbal-balik antara guru dengan siswa dalam mencapai tujuan belajar, membuat siswa belajar secara aktif dan menekankan pada penyediaan sumber belajar. Proses pembelajaran mampu memberikan pemahaman yang baik, kecerdasan, ketekunan, kesempatan dan mutu serta dapat memberikan perubahan prilaku dan mengaplikasikannya dalam kehidupan sehari-hari. Guru hanya berperan sebagai motivator dan fasilitator dengan terus berusaha menciptakan suasana belajar yang kondusif dan menyenangkan sehingga siswa lebih giat dalam mengembangkan potensi yang ada pada dirinya.

Biologi adalah salah satu ilmu pengetahuan alam (IPA) yang berkaitan erat dengan cara mencari tahu dan memahami alam semesta secara sitematis, sehingga Biologi bukan hanya merupakan penguasaan kumpulan pengetahuan yang berupa fakta-fakta, konsep-konsep dan prinsip-prinsip saja tetapi juga merupakan suatu proses menemukan.

Pembelajaran biologi berhubungan dengan alam nyata dan berkaitan dengan proses-proses kehidupan. Agar siswa dapat memahaminya, maka metode dan pendekatan yang digunakan dalam proses pembelajaran biologi harus disesuaikan dengan karakteristik objek dan subjek belajarnya. Pembelajaran biologi diharapkan mampu menjawab tentang fenomena alam dan makhluk hidup yang ada didalamnya dan mampu menunjang perkembangan ilmu pengetahuan dan teknologi yang berguna bagi kemaslahatan masyarakat yang dapat dilihat dari hasil kreativitas siswa. Seseorang dikatakan kreatif apabila terjadi perubahan yang menghasilkan sesuatu yang baru.

Kreativitas merupakan kemampuan seseorang untuk melahirkan sesuatu yang baru baik berupa gagasan maupun karya nyata, yang relatif berbeda dengan apa yang telah ada sebelumnya. Jadi, kreativitas merupakan hasil dari interaksi antara individu dan lingkungannya karena antara individu dan lingkungan adalah saling mempengaruhi dalam menunjang atau menghambat upaya kreatif. Siswa yang memiliki kreativitas belajar yang baik biasanya menunjukkan ciri-ciri seperti rasa ingin tahu yang luas dan mendalam, sering mengajukan pertanyaan yang baik, memeberikan banyak gagasan dan usul terhadap suatu masalah, bebas dalam menyatakan pendapat, mampu melihat masalah dari berbagai sudut pandang, mempunyai rasa humor yang luas dan mempunyai daya imajinasi.

Peneliti melakukan observasi terhadap aktivitas belajar siswa di kelas XI IPA-4 SMA Negeri 1 Sipirok, diperoleh hasil bahwa pada saat proses pembelajaran berlangsung, rasa ingin tahu siswa masih rendah, siswa tidak mampu mengajukan pertanyaan atau gagasan dengan baik, kurang berani mengutarakan pendapat, tidak mampu melihat masalah dari berbagai sudut pandang, kaku dalam belajar dan belum mampu berimajinasi. Dari 32 siswa yang diamati, hanya 13 orang $(53,12 \%)$ siswa yang memiliki aktivitas dengan kriteria baik sedangkan sisanya 15 orang (46,87\%) dinyatakan memiliki aktivitas belajar dengan kriteria kurang.

Menurut Sudjiono (2011) keberhasilan belajar siswa dapat ditentukan oleh kreativitas belajar yang dimilikinya. Siswa yang memiliki kreativitas belajar tinggi cenderung 
prestasinya pun akan tinggi pula, sebaliknya siswa yang kreativitas belajarnya rendah, akan rendah pula prestasi belajarnya.

Berdasarkan hasil wawancara yang dilakukan penulis, menyatakan bahwa model pembelajaran yang diterapkan dalam menyampaikan materi adalah model pembelajaran langsung dengan langkahlangkah pembelajaran dimulai dari menyampaikan tujuan pembelajaran, mendemonstrasikan pengetahuan, membimbing pelatihan, mengecek pemahaman dan memberikan umpan balik lalu diakhiri dengan pemberian kesimpulan pelajaran.

Untuk memperkuat fakta di atas, peneliti memberikan tes kreativitas dengan mengukur 5 indikator kreativitas melalui 10 soal essay test pada materi pokok keanekaragaman hayati yang diikuti oleh 32 orang siswa dan hasilnya tidak jauh berbeda dari nilai ulangan harian siswa, yakni hanya 11 (34,37\%) siswa yang tuntas, sementara sisanya $21 \quad(65,62 \%)$ siswa dinyatakan tidak tuntas dengan kriteria ketuntasan minimal (KKM) 75 dan nilai rata-rata kelas yaitu 63,67 (kualifakasi rendah). Data ini menunjukkan bahwa semakin tinggi kreativitas yang dimiliki siswa maka akan semakin tinggi pula hasil belajarnya dan sebaliknya, siswa yang memliki kreativitas belajar rendah biasanya akan mengalami kesulitan belajar sehingga hasil belajarnya pun akan rendah pula.

Sebagai seorang guru biologi, hendaknya mampu memberi pengalaman belajar kepada siswa melalui kegiatan pengamatan dan eksperimen, mendiskusikan hasilnya, dan menarik kesimpulan. Guru biologi juga perlu mengembangkan kreativitas siswanya agar mereka lebih mampu menangani dan mengarahkan belajar bagi mereka sendiri, memberi penguatan dan memperlihatkan bahwa belajar biologi yang baik bukan dengan cara menghafal.

Uraian di atas cukup menjelaskan bahwa model pembelajaran sangat mempengaruhi kreativitas belajar siswa. Kreativitas belajar begitu penting bagi siswa karena dengan berkreasi siswa bisa mewujudkan dirinya menjadi lebih baik. Perwujudan diri ini merupakan salah satu kebutuhan pokok didalam belajar. Sebuah kreativitas adalah kemampuan untuk melihat berbagai macam kemungkinan tentang penyelesaian akan suatu permasalahan. Suatu kreatifitas tidak hanya berguna namun juga memberikan kepuasan bagi siswa.

Menurut Ramayulis (2012) problem based learning (PBL) merupakan model dimana peserta didik diharapkan pada suatu kondisi bermasalah, untuk itu ia harus menemukan sejumlah strategi untuk dapat memecahkan masalah tersebut. Pembelajaran dengan model PBL ini menekankan kepada peserta didik untuk menemukan jawaban sendiri. Dengan model ini peserta didik dapat mengembangkan kemampuan berfikir secara kreatif dan menyeluruh, karena dalam proses belajarnya, peserta didik banyak melakukan aktivitas kreatif .

Dari pendapat diatas dapat disimpulkan bahwa kegiatan problem based learning ditujukan untuk mengembangkan keterampilan proses dengan merumuskan pertanyaan yang mengarahkan kepada kegiatan. Melalui model pembelajaran PBL ini diharapkan peserta didik dapat mengembangkan kemauan belajar, dan kreativitas belajar siswa semakin meningkat. Adapun tujuan penelitian ini adalah untuk mengetahui peningkatan kreativitas dan aktivitas belajar biologi siswa serta pengelolaan pembelajaran biologi melalui penerapan model pembelajaran problem based learning.

\section{METODE}

Jenis penelitian ini ialah Penelitian Tindakan Kelas (PTK) yang dilaksanakan di SMA Negeri 1 Sipirok, Kecamatan Sipirok, Kabupaten Tapanuli Selatan Provinsi Sumatera Utara selama 2 bulan 
mulai dari tanggal Mei sampai dengan Juli 2018. Prosedur pelaksanaan penelitian tindakan kelas ini terdiri dari dua siklus yang mana setiap siklus terdiri atas dua kali pertemuan sehingga dari dua siklus ada empat kali pertemuan.

\section{Siklus I}

Prosedur peneltian pada siklus I dimulai dari tahap perencanaan dimana tim peneliti melakukan analisis kurikulum untuk mengetahui kompetensi dasar yang disampaikan kepada siswa dengan model problem based learning, embuat rencana pelaksanaan pembelajaran (RPP) dengan menggunakan model pembelajaran problem based learning, membuat instrumen yang digunakan dalam siklus PTK, membuat rencana lembar kerja siswa (LKS) dan enyusun alat evaluasi pembelajaran siswa.

Tahap pelaksanaan dilakukan sesuai dengan langkah-langkah model pembelajaran problem based learning, yaitu: orientasi masalah, mengorganisasi siswa untuk belajar, membimbing penyelidikan individual maupun kelompok, mengembangkan dan menyajikan hasil karya dan enganalisis dan mengevaluasiproses pemecahan masalah. Tahap pengamatan dilakukan dengan melakukan pengamatan terhadap aktivitas belajar biologi siswa dan pengelolaan pembelajaran biologi sedangkan tahap refleksi dilakukan oleh tim peneliti melaksanakan diskusi untuk mengetahui kekurangan-kekurangan pada siklus pertama untuk diperbaiki pada siklus berikutnya.

\section{Siklus II}

Melaksanakan pembelajaran dengan model problem based learning pada materi struktur dan fungsi sel dengan langkah-langkah sesuai model problem based learning

Tahap I orientasi siswa pada masalah; memberikan salam dan mengabsen siswa, guru menjelaskan tujuan pembelajaran, alat, dan media yang dibutuhkan, mengajukan fenomena atau demonstrasi atau cerita untuk memunculkan masalah pada system indra, memotivasi siswa untuk terlibat dalam pemecahan masalah yang dipilih. Tahap II; mengorganisasi siswa untuk belajar, guru membantu siswa untuk mendefinisikan dan mengorganisasikan tugas belajar yang berhubungan dengan masalah terhadap macam-macam tersebut. Tahap III; membimbing penyelidikan individual maupun kelompok, guru mendorong siswa untuk mengumpulkan informasi yang sesuai tentang sistem alat indra melaksanakan eksperimen, untuk mendapatkan penjelasan dan pemecahan masalah. Tahap IV; mengembangkan dan menyajikan hasil karya, guru membantu siswa dalam merencanakan dan menyiapkan karya yang sesuai seperti laporan, video, dan model serta membantu mereka untuk berbagi tugas dengan temannya. Tahap V ; menganalisis dan mengevaluasi proses pemecahan masalah. guru membantu siswa untuk melakukan refleksi atau evaluasi terhadap penyelidikan mereka dan proses-proses yang mereka gunakan dalam memahami indicator dalam pembelajaran.

\section{Analisis Data}

\section{A. Menetukan Nilai}

Nilai hasil tes belajar siswa dapat ditentukan dengan menjumlahkan skor perolehan siswa dibagi skor maksimal dikali $100 \%$

$$
\text { Nilai }=\frac{\text { skor perolehan siswa }}{\text { skor maksimal }} \times 100 \%
$$

Setiap lembar jawaban siswa dikoreksi untuk mengetahui tingkat hasil belajar biologi. Untuk mengetahui tingkat hasil belajar biologi siswa diperoleh dengan menggunakan rumus skala Sudjiono (2011) .

\section{B. Menentukan Mean}

Menentukan mean atau nila ratarata dapat dilakukan dengan menjumlahkan semua nilai perolehan 
PeTeKa (Jurnal Penelitian Tindakan Kelas dan Pengembangan Pembelajaran)

Vol 2 No 1 Tahun 2019 Hal 30-38

siswa (nilai total) dan membagi jumlah tersebut dengan jumlah seluruh siswa. Adapun rumus sederhana yang digunakan adalah sebagai berikut:

Nilai Rata - Rata $=\frac{\text { Jumlah Nilai Total }}{\text { Jumlah Seluruh Siswa }}$

\section{Menentukan PKK}

PKK perlu dihitung untuk mengetahui tingkat keberhasilan tes hasil belajar yaitu dengan rumus sederhana sebagai berikut:

$$
\mathrm{PKK}=\frac{\mathrm{x}}{\mathrm{n}} \times 100 \%
$$

$$
\begin{array}{ll}
\text { PKK } & \text { : Persentase Ketuntasan Klasikal } \\
\mathrm{X} & \text { : Jumlah siswa yang tuntas } \\
\mathrm{n} & \text { : jumlah seluruh siswa }
\end{array}
$$

\section{Aktivitas Belajar Siswa}

Dari hasil pengamatan aktivitas belajar siswa selama kegiatan pembelajaran dianalisa berdasarkan persentase. Persentase aktivitas siswa yaitu frekuensi setiap aspek pengamatan dibagi dengan jumlah frekuensi semua aspek pengamatan dikali $100 \%$.

$\%$ Aktivitas $=\frac{\text { F. Setiap Pengamatan }}{\text { jlh F.Semua Pengamatan }} \times 100 \%$

\section{E. Pengelolaan Pembelajaran}

Dari hasil pengamatan kinerja guru selama kegiatan pembelajaran dianalisa berdasarkan persentase kinerja guru. Persentase kinerja guru yaitu frekuensi setiap aspek pengamatan dibagi dengan jumlah frekuensi semua aspek pengamatan dikali $100 \%$.

$\%$ Altivitas $=\frac{\text { F. Setiap Pengamatan }}{\text { jlh F.Semua Pengamatan }} \times 100 \%$

Nilai dari hasil perhitungan persentase kinerja guru kemudian dianalisis berdasarkan skala analisa data.

\section{HASIL DAN PEMBAHASAN}

\section{A. Kreativitas Belajar Siswa}

Slameto (2003) menjelaskan bahwa pengertian kreativitas berhubungan dengan penemuan sesuatu, mengenai hal yang menghasilkan sesuatu yang baru dengan menggunakan sesuatu yang telah ada. Sesuatu yang baru itu mungkin berupa perbuatan atau tingkah laku, bangunan, dan lain-lain.

Teori ini lebih cenderung menegaskan bahwa kreativitas baru akan muncul jika ada sesuatu yang telah ada sebelumnya. Artinya, kreativitas hanya berupa pengembangan dari yang sudah ada, maka setelah melakukan analisa data terhadap tes kreativitas diperoleh data nilai rata-rata pada siklus I 80,31 dan pada siklus II menjadi 82,87 (peningkatan 2,86) dengan jumlah siswa yang tuntas dari siklus I 23 orang menjadi 30 orang pada siklus II (peningkatan 7 orang). Secara keseluruhan penerapan model problem based learning dapat meningkat kreativitas siswa dari silkus I dengan persentase ketuntasan $71,87 \%$ pada siklus II menjadi 93,75\% pada siklus II (Peningkatan 21,88\%).

Jika kita lihat kondisi real kelas melalui indikator kreativitas yang dinilai maka diperoleh hasil tes dari siklus I ke siklus II dapat kita lihat bahwa adanya peningkatan kreativitas belajar siswa dari siklus I ke siklus II. Hal ini dapat dibuktikan dari hasil tes yaitu kemampuan fleksibilitas siswa dalam mengerjakan soal dari siklus I 72,30 menjadi 93,02 (meningkat 23,62\%). Sementara itu, siswa sudah memiliki nilai originalitas yang tinggi dengan perolehan nilai 71,15 menjadi 92,92 (meningkat 24,82\%). Siswa sudah mampu berelaborasi dan fluency dengan nilai peningkatan dari siklus I ke siklus II masing-masing 26.85\% dan 24.68\%.

Dari gambar 1 dapat kita lihat bahwa nilai hasil tes dari indikator yang satu dengan indikator yang lain tidak jauh berbeda bahkan hampir mencapai nilai rata-rata yang sama, artinya siswa yang diteliti memang benar-benar memiliki kreativitas belajar yang homogen antara kterampilan yang satu dengan keterampilan yang lain sebagaimana 
yang dijelaskan oleh Drevhdal (dalam Munandar, 2009) bahwa kreativitas sebagai kemampuan untuk memproduksi komposisi dan gagasan-gagasan baru yang dapat terwujud aktivitas imajinatif atau sintesis yang mungkin melibatkan pembentukan pola-pola baru dan kombinasi dari masa lalu yang dihubungkan dengan yang sudah ada pada situasi sekarang. Teori ini menegaskan bahwa hasil kreativitas sangat berguna, bertujuan, terarah dan tidak hanya sekedar fantasi. Dalam hal ini, kemampuan imajinatif siswa yang dimaksud adalah dalam memecahkan persoalan terkait dengan materi yang sedang dpelajari.

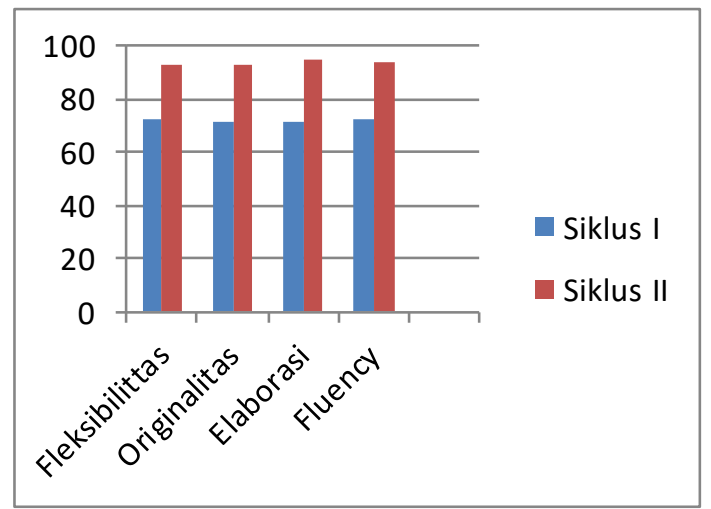

Gambar 1. Hasil Observasi Aktivitas Siswa Siklus I dan Siklus II

\section{B. Aktivitas Belajar Siswa}

Aktivitas belajar merupakan segala kegiatan yang dilakukan dalam proses interaksi (guru dan siswa) dalam rangka mencapai tujuan belajar. Aktivitas yang dimaksudkan di sini penekanannya adalah pada siswa, sebab dengan adanya aktivitas siswa dalam proses pembelajaran terciptalah situasi belajar aktif sebagaimana yang dikemukakan oleh Natawijaya (dalam Depdiknas, 2005) bahwa belajar aktif adalah suatu sistem belajar mengajar yang menekankan keaktifan siswa secara fisik, mental, intelektual dan emosional guna memperoleh hasil belajar berupa perpaduan antara aspek kognitif, afektif dan psikomotorik.

Trinandita (dalam Yasa, 2008) menyatakan bahwa hal yang paling mendasar yang dituntut dalam proses pembelajaran adalah keaktifan siswa”. Keaktifan siswa dalam proses pembelajaran akan menyebabkan interaksi yang tinggi antara guru dengan siswa atau pun siswa dengan siswa. Teori ini menjelaskan bahwa masing-masing siswa dapat melibatkan kemampuannya semaksimal mungkin. Dari teori tersebut, peneliti mencoba mengumpulkan data tentang hasil observasi aktivitas belajar siswa, dapat dijelaskan bahwa pada siklus I nilai rata-rata persentase aktivitas 58,28\% dengan kriteria cukup dan meningkat pada siklus II, rata-rata persentase aktivitas siswa sebesar $76,56 \%$ dengan kriteria baik sehingga dari siklus I ke siklus II terjadi peningkatan sebasar 18,28\% dari kulaifikasi kurang menjadi kriteria baik. Dengan demikian, kriteria ketuntasan klasikal (PKK) sebesar 75\% telah tercapai.

Aktivitas belajar yang timbul dari siswa akan mengakibatkan terbentuknya pengetahuan dan keterampilan yang akan mengarah pada peningkatan prestasi. Hal ini sejalan dengan pendapat Dimyati (dalam Adijaya, 2004) yang menyatakan bahwa aktivitas belajar siswa selama proses pembelajaran merupakan salah satu indikator adanya keinginan siswa untuk belajar. Dari semua hasil observasi aktivitas belajar siswa dengan menggunakan model problem based learning (PBL) pada materi struktur dan fungsi sel.

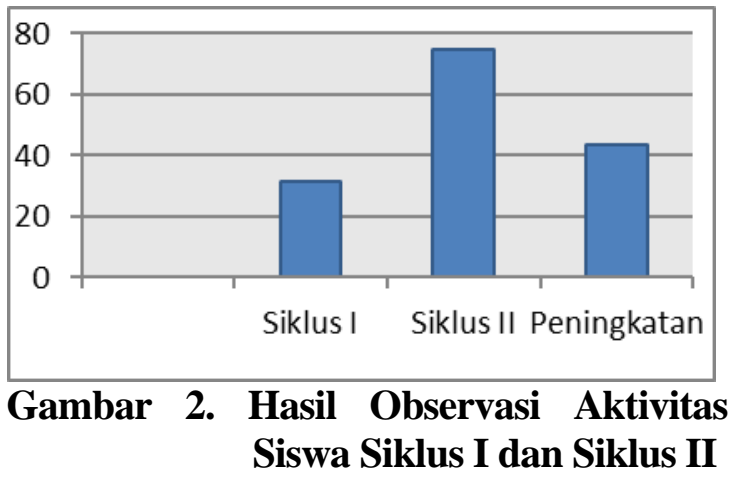

Selain observasi melalui indikator aktivitas belajar di atas, peneliti juga melihat kondisi real di kelas seperti aktivitas bertanya pada guru dimana pada awal pembelajaran siswa sperti masih bingung dengan penerapan model problem based learning 
yang mulai diperkenalkan oleh guru namun seiring berjalannya waktu yaitu pada siklus II siswa sudah paham dengan proses belajar mengajar sehingga perilaku menanggapi pertanyaan dari guru/teman sudah meningkat, siswa sudah mampu mengutarakan pendapat sendiri dan teliti serta bekerja sama yang baik dalam kerja kelompok (kulaifikasi baik). Selain itu, siswa juga sudah mampu mengajukan pendapat terhadap informasi yang disampaikan oleh guru atau siswa lain, memberikan respon yang nyata terhadap stimulus belajar, melakukan penilaian sendiri terhadap hasil pekerjaannya, sekaligus memperbiki dan menyempurnakan hasil pekerjaan yang belum sempurna, membuat kesimpulan pelajaran dengan bahasanya sendiri dan memanfaatkan sumber belajar atau lingkungan belajar yang ada disekitarnya secara optimal.

\section{Pengelolaan Pembelajaran Biologi}

Pengelolaan pembelajaran atau kinerja guru sangat penting untuk dipertahankan dan dievaluasi karena guru mengemban tugas professional artinya tugastugas hanya dapat dikerjakan dengan kompetensi khusus yang diperoleh melalui program pendidikan. Untuk itu, dalam penelitian ini perlu di bahas menenai kemampuan guru dalam mengelola pembelajaran.

Berdasarkan hasil observasi aktivitas guru dalam mengelola pembelajaran secara keseluruhan menunjukkan bahwa pelaksanaan pembelajaran dengan menerapkan model problem based learning pada materi pokok struktur dan fungsi sel dalam penelitian ini berjalan dengan baik dan mengalami peningkatan selama pelaksanaan pembelajaran. Hal ini dibuktikan dengan perolehan nilai rata-rata total aktivitas guru dalam mengelola pembelajaran pada siklus I masih sebesar 2,8 dengan persentase 70\% atau berada pada kategori cukup. Sedangkan pada siklus II nilai rata-rata total yang diperoleh meningkat menjadi 3,3 dengan persentase $91 \%$ atau berada pada kategori sangat baik. Dengan demikian telah terjadi peningkatan hasil pengelolaan pembelajaran biologi dari siklus I ke siklus II sebesar 21\% dari kriteria cukup menjadi sangat baik. Untuk hasil yang lebih jelas mengenai peningkatan kadar aktivitas guru dalam mengelola pembelajaran dari siklus I ke siklus II dapat dilihat pada tabel 3.

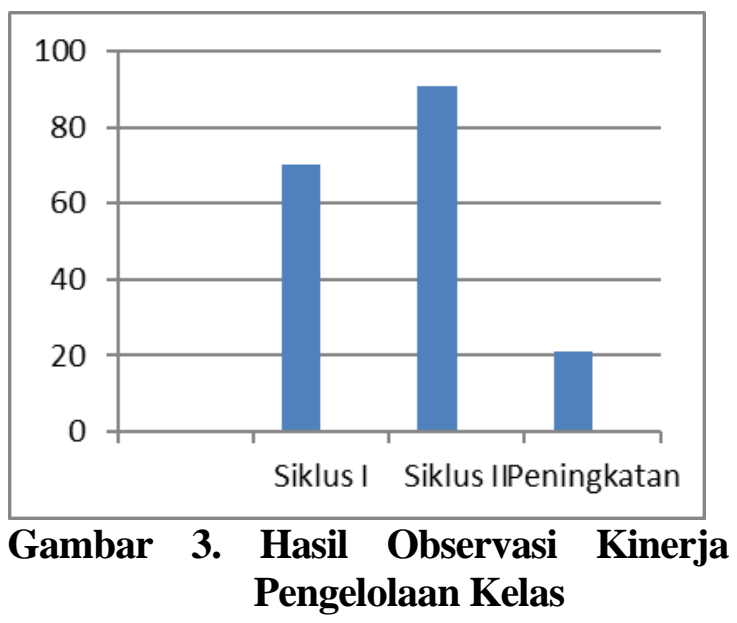

Setelah semua siklus selesai dilakukan, maka dapat disimpulkan bahwa dengan menggunakan model problem based learning pada materi struktur dan fungsi sel terlihat siswa lebih aktif dalam mengikuti pembelajaran, selain itu siswa lebih memahami materi pokok yang dipelajari dan motivasi belajar siswa juga meningkat.

Guru menjelaskan bahwa pengelolaaannya lebih baik dengan menggunakan model problem based learning pada materi struktur dan fungsi sel serta konsep-konsep yang ada pada materi pembelajaran lebih mudah dimengerti dan dipahami. Dari hal tersebut dapat kita simpulkan bahwa kinerja guru sangat penting untuk dipertahankan dan dievaluasi karena guru mengemban tugas professional artinya tugas-tugas hanya dapat dikerjakan dengan kompetensi khusus yang diperoleh melalui program pendidikan, sebagaiaman yang telah di uatarakan oleh Danim (2002) bahwa guru memiliki tanggung jawab yang secara garis besar dapat dikelompokkan yaitu guru sebagai pengajar, guru sebagai pembimbing dan guru sebagai administrator kelas.

Hal serupa juga dikemukakan oleh Deporter (2000) seseorang yang memiliki 
kompetensi, yaitu: selalu berorientasi pada hasil, memperhatikan prosedur dalam mengidentifikasi dan menilai hasil proses pembelajaran, memiliki pengalaman, memiliki pengetahuan formal dan informal serta berprilaku terhadap kemajuan. kompetensi guru adalah suatu performansi (kemampuan) yang dimiliki seorang guru meliputi aspek pengetahuan, keterampilan, proses berpikir, penyesuaian diri, sikap dan nilai-nilai yang dianut dalam melaksanakan profesi sebagai guru. Dalam melaksanakan kegiatan, seorang guru berpikir dan bertindak secara konsisten dan terus menerus sesuai dengan kompetensinya. Lebih lanjut peneliti menemukan rasa senang dan daya terima siswa terhadap model pembelajaran yang diterapkan oleh guru. Hal ini dibuktikan melalui keterlibatan siswa dalam bertanya, mengutarakan pendapat dan membuat kesimpulan. Siswa sendiri mengaku dengan penerapan model problem based learning membuat siswa lebih memahami materi yang diajarkan oleh guru.

Berdasarkan data dan pemaparan di atas, dapat disimpulkan bahwa pada hakikatnya, pengelolaan pembelajaran bukan hanya sebatas melaksanakan kurukulum sebagai beban kerja, tetapi justru banyak tugas laian yang harus dilaksanakan dan itu terwujud dalam bentuk kinerja seorang guru. Pengelolaan pembelajaran guru berada dalam rumusan melaksanakan tugas serta mewujudkan kompetensi dalam mengemban amanah pendidikan yang ada dipundaknya.

\section{SIMPULAN}

Berdasarkan tujuan penelitian, hasil penelitian dan pembahasan, maka penelitian yang dilaksanakan di SMA Negeri 1 Sipirok dapat disimpulkan sebagai berikut : (1) Penerapan model problem based learning (PBL) dapat meningkatkan kreativitas belajar siswa pada pokok bahasan struktur dan fungsi sel di kelas XI IPA-4 SMA Negeri 1 Sipirok tahun pelajaran 2018-2019. Dapat dilihat dari hasil hasil tes kreativitas pada siklus I memperoleh nilai persentase ketuntasan 71,97\% dan siklus II 93,75\% (peningkatan sebesar 21,88\%); (2) Dengan menggunakan model problem based learning (PBL)dapat meningkatkan aktivitas belajar siswa kelas XI IPA-4 pada materi struktur dan fungsi sel di SMA Negeri 1 Sipirok TP 2018-2019. Hal ini dapat dilihat pada siklus I nilai persentase sebesar 58,28\% dan meningkat pada siklus II dengan persentase 76,56\% sehingga dari siklus I ke siklus II terjadi peningkatan sebasar 18,28\% dari kulaifikasi kurang menjadi kriteria baik; (3) Kemampuan guru dalam mengelola pembelajaran biologi di kelas XI IPA-4 SMA Negeri 1 Sipirok pada materi struktur dan fungsi sel dapat meningkat melalui penerapan model problem based learning. Hal ini dapat dilihat dari hasil observasi siklus I diperoleh nilai rata-rata 2,8 dan persentase kinerja sebesar 70\% dengan kriteria cukup, dan pada siklus II diperoleh nilai rata-rata 3,3 (91\%)dengan kriteria sangat baik. Sehingga dari siklus I ke siklus II telah terjadi peningkatan sebesar $21 \%$.

\section{DAFTAR PUSTAKA}

Adijaya.(2004). Hakekat Belajar, Prestasi Belajar dan Aktivitas Belajar. Jakarta: Raja Grafindo

Danim, S. (2002) Menjadi Peneliti Kualitatif. Bandung: CV. Pustaka Setia.

Depdiknas. (2003), Standar Kompetensi Mata Pelajaran IPA Dan MI. Jakarta: Depdiknas.

Deporter. (2000). Pembelajaran Quantum Teaching. Jakarta: Rineka Cipta

Munandar. (2009). Kreativitas Pembelajaran. Medan: Cv. Iskom

Ramayulis. (2012). Ilmu Pendidikan Islam. Jakarta: Kalam Mulia

Slameto.(2013), Belajar Dan FaktorFaktor Yang Mempengaruhinya. Jakarta: Rineka Cipta. 
PeTeKa (Jurnal Penelitian Tindakan Kelas dan Pengembangan Pembelajaran)

Vol 2 No 1 Tahun 2019 Hal 30-38

Sudjiono.(2011), Pengantar Statistik

Pendidikan. Jakarta: Raja

Grapindo.

Yasa, Doantara. (2008). Aktivitas dan

Prestasi Belajar. Jakarta: Raja

Grapind 